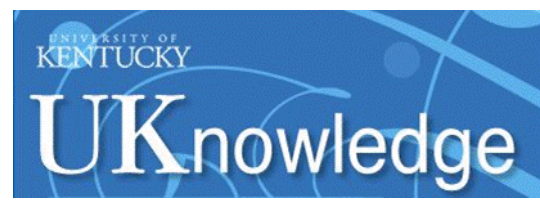

University of Kentucky

UKnowledge

Pediatrics Faculty Publications

Pediatrics

$7-2003$

\title{
Adolescent Violence Prevention: A Case Presentation
}

Hatim A. Omar

University of Kentucky, hatim.omar@uky.edu

Joan Griffith

University of Kentucky, joan.griffith@uky.edu

Follow this and additional works at: https://uknowledge.uky.edu/pediatrics_facpub

Part of the Pediatrics Commons

Right click to open a feedback form in a new tab to let us know how this document benefits you.

\section{Repository Citation}

Omar, Hatim A. and Griffith, Joan, "Adolescent Violence Prevention: A Case Presentation" (2003).

Pediatrics Faculty Publications. 71.

https://uknowledge.uky.edu/pediatrics_facpub/71

This Article is brought to you for free and open access by the Pediatrics at UKnowledge. It has been accepted for inclusion in Pediatrics Faculty Publications by an authorized administrator of UKnowledge. For more information, please contact UKnowledge@lsv.uky.edu. 


\section{Adolescent Violence Prevention: A Case Presentation}

Digital Object Identifier (DOI)

http://dx.doi.org/10.1515/IJAMH.2003.15.3.281

\section{Notes/Citation Information}

Published in International Journal of Adolescent Medicine and Health, v. 15, no. 3, p. 281-284.

(c) Freund Publishing House Ltd.

The copyright holder has granted permission for posting the article here. 


\title{
Adolescent violence prevention: A case presentation
}

\author{
Hatim Omar, MD and Joan Griffith, MD
}

Section of Adolescent Medicine, Department of Pediatrics, University of Kentucky, Lexington, $K Y$, United States of America

Abstract: Violence in adolescence has seen an increase since the 1990 s with dramatic statistics on violent death and risk behaviors. School violence has been focused upon by a huge media coverage of especially violent cases that could have had some endemic consequences worldwide. We present a case of a 14 year old white male with change in school behavior, strategies for the case investigation, its results, and long term prevention. Other research has shown that preventive measures during pregnancy, infancy and childhood can prevent adolescent and adult delinquency.

Keywords: Adolescent violence, case report, United States

Correspondence: Hatim Omar, MD, Director, Adolescent Medicine, Dept. of Pediatrics, Room J422, KY Clinic, University of Kentucky Medical Center, Lexington, KY 40536-0284 United States of America. Tel: (859) 323-5643. Fax : (859)257-7706. E-mail: haomar2@uky.edu :

Submitted: Janary 24, 2003. Revised: February 24, 2003. Accepted: February 25, 2003.

\section{INTRODUCTION}

Homicide rates in the United States are the highest of any developed country and adolescents are at the highest risk of violent death (1). Prevailing rates of lethal and nonlethal violence among adolescents are at an all time high (2). School-associated violence became widely recognized as a common and increasing problem in the mid-1990s (3-5). Adolescent violence represents a public health concern, because of its potential to adversely affect the emotional and social development of the perpetrators, victims and witnesses (6). It is generally accepted that antisocial behavior that begins in early childhood continues to adolescence and adulthood (7).

\section{CASE REPORT}

$C D$ was a 14 year-old white male in $6^{\text {th }}$ grade referred to the adolescent clinic for evaluation by his school, because of deteriorating grades and suspensions for non-compliance with class rules of conduct. This is a special arrangement with the school authorities, where our clinic provides risk assessment, counseling and intervention for students within a schoolbased health promotion center.

During the initial interview the patient was hostile, uncooperative and insisting that he was well and did not need help. However, after we explained that based on the school evaluation he would be suspended again or transferred to a specialized school for problem teens if unwilling to cooperate, he agreed to go along with the interview. In response to our specific questioning, he admitted that he had been acting inappropriately in class. He blamed his behavior on the "bad teachers" who "do not know anything".

On questioning about his home situation, he claimed that his father and stepmother were drug addicts and child abusers. He went on to say that he did not need his parents or anybody else, since he already ran his own "business" and had enough money. The business consisted of selling drugs to peers at school and on the 
street. He admitted to smoking, drinking alcohol and drug use (marihuana, inhalants and crack cocaine) on a daily basis. He denied being depressed or having any thoughts about suicide.

When asked why he did not report being abused at home, he said that this was when he "was a kid" and now he can "beat his father up". He denied access to firearms, but admitted using a pocket knife he carried taped to his ankle and proceeded to show it in clinic. At this time we interviewed the father and stepmother, who appeared to be genuinely concerned about $\mathrm{CD}$. They disclosed that $C D$ had changed in the last four months and they could barley recognize him anymore. They did not know what caused the change.

The only new thing in his life appeared to be his new group of friends, who were older with school problems. The parents denied ever abusing CD in any form and were very cooperative with child protective services. Interviews with relatives and neighbors as well as home inspections collaborated the story and their two other children (ages 10 and 12 years) denied any abuse and expressed concern about $C D$. He was allowed to go to school the next day and to come back to our clinic after school.

One day later $C D$ was suspended again from school for possession of marihuana on school premises. During our second interview with $C D$ we felt he was cooperative but extremely hostile toward the school, especially the teachers and two of his classmates that reported him to the teachers for drug use. He repeatedly said "They will be sorry", but refused to specify how. At this point we felt that this patient presented a possible threat for himself and others. We contacted the parents, who denied having any firearms in the house. We contacted the police to check if they had any information about any illegal weapon purchase or theft in his neighborhood and were told that CD's next door neighbor had reported that someone had broken the widows of his car and his gun was missing from the car. The police requested permission from CD's parents to search the house, which was granted. The stolen gun was found in CD's room together with a note listing the names of three teachers and seven of his classmates with the phrase "will die" at the bottom of the list.

After this, CD admitted to police that he was planning to take the gun and "punish" those people, who "hated him". He also supplied the names of three older teens who supplied him with drugs for his own use and for sale. A juvenile court ordered $C D$ admitted to a psychiatric hospital for further evaluation and assessment. He was diagnosed with bipolar disorder and substance abuse and is now under treatment. The drug distributors were arrested and are under investigation.

\section{DISCUSSION}

This case illustrates the complexity of adolescent development and the multiple factors leading to violence or potential violence. Drug use, lack of communication with adults (parents, teachers), mental health problems, exposure to violence in the media or in real life with negative peer influence can lead to violence. This can happen specifically in young adolescents that have not yet developed abstract thinking.

Children immersed in communities that expose them to violence have been shown to be at high risk for victimization and perpetration of violence (8). Viewing violence on television has been linked with imitative violence, aggressive behavior, acceptance of hostility, and willingness to deliver painful stimuli to others (9). Additional adverse effects on the mental and physical health of children exposed to violence include the emergence of Posttraumatic Stress Disorder (PTSD), internalizing states such as anxiety and 
depression, and externalizing behaviors such as aggression and risking-taking (6).

Important risk factors for delinquency and violence include poor parenting, untreated conduct disorder, social stress, poverty, and school failure (7). Valois et al (10) detailed six major categories (individual, family, school/academic, peerrelated, community and neighborhood, and situational) as they relate to risk factors and behaviors associated with adolescent aggression and violence.

Many of the secondary and tertiary prevention programs that focus on incarceration and rehabilitation have not significantly decreased the rate of recidivism. It has been suggested that the most successful prevention programs are likely to be those concentrated in childhood as primary prevention (2). It is thought that through early, supportive involvement with significant adults, adolescents will develop greater self-determination and improved behavior (11).

\section{CONCLUSIONS}

The complex and interactive components of adolescent violence require a preventive plan comprised of comprehensive community partnership. In the case presented. here, cooperation between multiple agencies was a key in preventing potential violence. As in confronting other risky behaviors, the development of a close working relationship between committed agencies and individuals (parents, police, social services, community health workers, schools and voluntary agencies) was of critical importance (12).

\section{REFERENCES}

1. Sege RD. Adoles Health Update. 1999;12(1).

2. Rachuba, L, Stanton B, Howard D. Violent crime in the united states: an epidemiologic profile. Arch Pediatr Adolesc Med 1995;149:953-60.

3. Sheley JF, McGee ZT, Wright JD.Gunrelated violence in and aroundinner-city schools. Am J Dis Child 1992;146:67782.

4. National School Board Association. Violence in the schools: How America's school Boards are safeguarding our children. Alexandria, VA: National School Boards Association, 1993.

5. National League of Cities. School Violence in America's Cities: NLC Survey Overview. Washington, DC: National League of Cities,1993.

6. Howard DE, Feigelman $\mathrm{S}, \mathrm{Li} X$, et al. The relationship among violence victimization, witnessing violence, and youth distress. $\mathrm{J}$ 'Adolesc Health 2002;31:455-62.

7. Rivara FP, Farrington DP. Prevention of violence. Arch Pediatr Adolesc Med 1995;149:421-9.

8. Bell CC, Jenkins EJ. Community Violence and children on Chicago's southside. Psychiatry 1993;56:446-54.

9. Sargent JD, Heatherton TF, Ahrens B, et al. Adolescent exposure to extremely violent movies. J Adolesc Health 2002;31:449-54.

10. Valois RF, MacDonald JM, Fischer BL, et al. Risk factors and behaviors associated with adolescent violence and aggression. Am J Health Behav 2002;26:454-64.

11. DiNapoli, PP. Adolescent violent behavior and ego development. $\mathrm{J}$ Adolesc Health 2002;31:449-54.

12. Christian J, Gilvarry E. Specialist services: the need for multi-agency partnership. Drug Alcohol Depend 1999; 55:265-74. 